Кірпічніков Ю. А., к.т.н.;

Андрощук О. В.;

Петрушен М. В.

Центр воєнно-стратегічних досліджень Національного університету оборони України імені Івана Черняховського, Київ

\title{
Аналіз поняття інтеграційної платформи та методів інтеграції даних інформаційних систем управління оборонними ресурсами
}

Резюме. Стаття розкриває поняття інтеграційної системи та їі роль для Збройних Сил України. Проаналізовано види інтеграційних систем, характеристики та методи інтеграції інформаційних систем.

Ключові слова: інформаційні системи, Збройні Сили України, інтеграція, методи інтеграції.

\begin{abstract}
Постановка проблеми. Останні
політичні та воєнні події змусили Україну жити в новій реальності і приймати блискавичні рішення у відповідь на актуальні виклики XXI століття. В умовах воєннополітичної кризи та ведення гібридної війни проти України однією з найбільш актуальних стала задача забезпечення керівних осіб органів військового управління різного рівня достовірною та своєчасною інформацією щодо матеріально-технічного забезпечення, управління особовим складом, фінансовоекономічної діяльності та іншими оборонними ресурсами для зменшення часу на прийняття рішень та своєчасного реагування на будь які зовнішні та внутрішні загрози та зміни у ситуації.
\end{abstract}

Протягом тривалого часу у Збройних Силах України для інформаційного забезпечення різних процесів управління оборонними ресурсами розвивали окремі автоматизовані, інформаційно-аналітичні та інформаційні системи (далі - IC), що не зв'язані між собою. Територіально розподілена інформаційна інфраструктура оборонного відомства країни сьогодні характеризується відокремленістю іiі складових та ізольованістю існуючих IC.

Розрізненість IC неминуче породжує проблему організації взаємодії між цими системами 3 метою отримання інформації, необхідної для прийняття рішень. Ця проблема також викликана великою різноманітністю існуючих IC, які використовують різні інформаційні технології та стандарти, формати та інтерфейси обміну даними. В цілому це призводить до дублювання інформації, недостовірності та несвоєчасності отримання даних, затримки прийняття рішень, порушення взаємодії між органами військового управління, що перешкоджає процесам контролю та управління оборонними ресурсами.

Ступінь розробленості проблеми. Одним 3 найбільш перспективних підходів до забезпечення взаємодії розрізнених IC для отримання повної та достовірної інформації $\epsilon$ використання інтеграційних технологій.

Інтеграційні технології дозволяють об'єднати окремі функціонально-орієнтовані IC, що не пов'язані між собою на технологічному рівні, в єдину інформаційну інфраструктуру 3 збереженням зроблених інвестицій та зменшенням витрат на впровадження нових систем та на їх інтеграцію існуючу інфраструктуру. Перевагами інтеграції $\epsilon$ зниження витрат на технічне обслуговування IC i закінчуючи спрощенням процесу прийняття рішень.

Найбільш ефективним рішенням даної проблеми $\epsilon$ використання так званого середовища інтеграції у вигляді деякої інтеграційної платформи.

Метою статті $\boldsymbol{\epsilon}$ визначення поняття та особливостей архітектури інтеграційної платформи на основі аналізу провідних підходів.

Виклад основного матеріалу. Інтеграційна платформа - програмно-апаратна інфраструктура, що дозволяе організувати обмін даними між розподіленими інформаційними системами, для підтримки, моніторингу та управління складовими бізнеспроцесами. Це інноваційний підхід до вирішення питань інтеграції, заснований на автоматизації наскрізних бізнес-процесів, в роботі яких задіяні різні інформаційні системи.

Інтеграція даних - об'єднання даних, що знаходяться в різних джерелах і надання даних користувачам в уніфікованому вигляді. 
Інтеграція програмних систем 1 продуктів - це обмін даними між системами 3 можливою подальшою їх обробкою.

Основною метою впровадження Інтеграційної платформи - $\epsilon$ створення в організації єдиного інформаційного середовища, що функціонує як цілісний механізм, що дозволяє ефективно вирішувати нагальні завдання оборонного відомства.

Інтеграційна платформа забезпечує більш тісний зв'язок існуючих систем і створює основу для автоматизації наскрізних бізнес-процесів, що представляють набору певних завдань i функцій, які залучають у взаємодію різні підрозділи та інформаційні системи оборонного відомства.

Інтеграційна платформа не $\epsilon$ місцем зберігання даних, вона лише являє собою сервер федералізації даних, що дозволяє організувати інтеграційні процеси для інформаційних систем при роботі інтеграційної платформи. Інтеграційна платформа виконує наступні функції:

- $є$ місцем зберігання метамоделі предметних даних i надає кошти для іiі модифікації;

- служить інструментом для створення, налаштування, виконання та контролю всіх інтеграційних процесів, де настройка інтеграційного процесу включає в себе зіставлення запитів на державну (муніципальну) послугу i необхідних відомостей інформаційних систем на основі метамоделі предметних даних;

- визначає режим обміну даними - за запитом, зі зміни даних, за розкладом і т.ін.;

- виконує перевірку достовірності і несуперечності даних, що надійшли від інформаційних систем. платформ:

Вигоди використання інтеграційних

- збереження інвестицій, вкладених в наявні системи за рахунок їх інтеграції в єдиний інформаційний комплекс шляхом створення єдиної транспортної магістралі Збройних Сил України на основі універсальної системи передачі повідомлень між додатками;

- підвищення ефективності управління бізнес-процесами в результаті використання повної несуперечливої інформації з декількох інтегрованих систем i організації “інтелектуального" обміну даними між різними додатками в уніфікованому вигляді в реальному часі;
- зниження впливу людського фактора i зменшення кількості помилок при ручному перенесенні інформації з системи в систему;

- зниження витрат часу на ручний пошук інформації в різних системах;

- зниження витрат на інтеграцію систем, які будуть створені в майбутньому, за рахунок спрощення підключення до інтегрованої системи додатків і надання вже накопиченої прикладної інформації;

- швидке i зрозуміле реагування на вимоги бізнесу за рахунок створення гнучких призначених для користувача сервісів;

- зменшення витрат ресурсів для взаємодії між партнерами i замовниками компанії за допомогою впровадження технології Business-to-Business (В2B) i Businessto-Client (B2C).

Можна виділити дві головні причини необхідності впровадження інтеграційної платформи для роботи з різними IC.

Перша полягає в тому, що в міру зростання кількості та функціонального розмаїття інформаційних систем Збройних Сил України технологічно i організаційно ускладнюються процеси забезпечення взаємодії інтеграційної платформи 3 окремо взятої інформаційної системи. Зростають також накладні витрати на забезпечення такої взаємодії, нерідкі випадки появи суперечливої інформації, посилюється значимість оперативності надання даних та ін.

Друга причина - забезпечення гнучкості і розвитку інтеграційної платформи при впровадженні нових інформаційних систем.

Основне призначення інтеграційної платформи - узгодження і гармонізація даних декількох інформаційних систем. Інтеграційна платформа оснащується спеціальними програмними адаптерами для збору в єдиній формі інформації від різних інформаційних систем, що відносяться до певної сфери діяльності.

Інтеграція даних включає об' єднання даних, що знаходяться в різних джерелах, i надання даних користувачам в уніфікованому вигляді. Роль інтеграції даних зростає, коли збільшується обсяг і необхідність спільного використання даних.

Системи інтеграції даних можуть забезпечувати інтеграцію даних на фізичному, логічному i семантичному рівні. Інтеграція даних на фізичному рівні з теоретичної точки зору є найбільш простим завданням і зводиться до конверсії даних 3 різних джерел в необхідний єдиний формат їх фізичного представлення. Інтеграція даних на логічному 
рівні передбачає можливість доступу до даних, що містяться в різних джерелах, в термінах єдиної глобальної схеми, яка описує їх спільне подання з урахуванням структурних i, можливо, поведінкових (при використанні об'єктних моделей) властивостей даних. Семантичні властивості даних при цьому не враховуються. Підтримку єдиного уявлення даних 3 урахуванням їх семантичних властивостей в контексті єдиної онтології предметної області забезпечує інтеграція даних на семантичному рівні.

Процесу інтеграції перешкоджає неоднорідність джерел даних, відповідно до рівня інтеграції.

При створенні системи інтеграції виникає ряд завдань, склад яких залежить від вимог до неї та використовуваного підходу. До них, зокрема, відносяться:

- розробка архітектури системи інтеграції даних;

- створення інтегрує моделі даних, що $є$ основою єдиного користувальницького інтерфейсу в системі інтеграції;

- розробка методів відображення моделей даних i побудова відображень в інтегруючу модель для конкретних моделей, які підтримуються окремими джерелами даних;

- інтеграція метаданих, які використовуються в системі джерел даних;

- подолання неоднорідності джерел даних;

- розробка механізмів семантичної інтеграції джерел даних.

Фактори, що впливають на інтеграцію:

Прискорення процесів. Розвиток оборонного відомства вимагає все частіше i частіше міняти структури даних, бізнеспроцеси, не кажучи вже про дизайн та інтерфейс користувача, який просто постійно знаходиться в зміні;

Розподіленість. Завдання можуть бути вирішені все більш комплексними, з'являється логічна, організаційна та географічна розпорошеність;

Гетерогенність. У великому проекті, майже ніколи немає можливості дотримуватися платформ та інструментів від одного виробника, тому доводиться враховувати і підтримувати особливості декількох платформ;

Спадковість. Неможливість повністю відмовитися від застарілих систем, морально застарілих технологій, старого апаратного забезпечення, які, до речі, іноді дають цілком хороші показники по надійності i продуктивності але вже аж ніяк не сприяють інтеграції.

Хаотичність. Не завжди є можливість повністю формалізувати, уточняти i структурувати дані, i частина моделі залишається “слабо-пов’язаної”, яка не піддається або слабо піддається машинній обробці, аналізу, індексації, обрахунку;

Обумовленість. На жаль, інформаційні системи обмежені не тільки технічними рамками, а й звичками людей (яких складно переучувати), особливостями законодавства (яке просто не готове до появи таких систем), безліччю інших чинників, не залежних від розробників;

Iнтерактивність. Споживач інформації постійно підвищує свої очікування про швидкість реакції системи, швидкодії i оперативності доставки інформації. Більшість процесів прагнуть до виконання в реальному часі;

Мобільність. Користувач систем став пересуватися швидше, а взаємодія 3 ним ведеться через канали зв'язку загального користування в транспорті, вдома і на вулиці, в громадських місцях і повсюдно;

Безпека. Поки дані зберігалися на носії всередині приміщення, що охороняється, то особливо ні хто не турбувався про шифрування, але тепер мережеві пакети літають в повітрі і це не можна залишати без уваги;

Високонавантаженість. На складність інтеграції впливають: кількість користувачів в системі, інтенсивність потоку обробки даних, обсяги даних і ресурсомісткість обчислень;

Безперервність цииклу роботи. Інтеграція i апгрейд систем майже завжди повинні проводитися без зупинки їх функціонування, плавно, поступово і непомітно для організації та її клієнтів;

Міжсистемна інтеграція. Завдання стикування не обмежені рамками організації, все частіше потрібно інтегруватися 3 партнерами, клієнтами, постачальниками, підрядниками та навіть державними структурами.

Сенс інтеграції полягає в тому, щоб дані, які користувач вводить в одну систему, автоматично переносилися в іншу. Продукт, в який користувач вводить дані, називається джерело. А одержувач даних, відповідно, приймач.

Досить часто дані переносять в обидві сторони, наприклад, після перетворення в системі-приймачі результати відправляються 
назад в джерело. А тому інтеграція буває як односторонньою, так і двосторонньою.

Слід розуміти, що при інтеграції інформаційних систем проводиться інтеграція саме даних, і тільки потім технічна реалізація каналу, способу, формату передачі даних. У зв'язку 3 цим, основною проблемою, яка виникає при інтеграції, є проблема, пов'язана 3 якістю даних. Виникають також організаційні труднощі і складності технічної реалізацій процесів.

Отже, до типових проблем інтеграції, пов'язаних 3 якістю даних, можна віднести: неузгодженість інтегрованих даних, в наслідок відсутності в компанії єдиної системи управління майстер-даними; не надавання важливості профілізації, аналізу та очищення даних перед реалізацією процесів інтеграції.

Резюмуючи перелік організащійних труднощів, можна сказати, що до них відносяться: відсутність відповідальних за інтеграційні процеси; недостатній адміністративний ресурс або несвоєчасне його застосування; відсутність відповідальних за якість даних; закритість служб супроводу i розробників інформаційних систем компанії Замовника; не притягнення до аналізу даних i подальшій розробці бізнес-правил перетворення предметних експертів Замовника.

До типових технічних проблем інтеграції, можна віднести: визначення джерела / приймача даних; аналіз даних джерела; вибір інструменту інтеграції; узгодження форматів, способу i періодичності обміну даними (узгодження регламенту інтеграціi); проектування і розробка процесів інтеграції; тестування; промислова експлуатація.

При цьому майже завжди основні труднощі виникають на етапах розробки i тестування. Але причини для їх появи закладаються раніше.

Починаючи 3 моделей розробки програмного забезпечення та розробки додатків, існує три рівня інтеграції програмного забезпечення: інтеграція даних, інтеграція сервісів і інтеграція процесів.

Інтеграція IC - об'єднання IC, що зв’язує безліч документів і відносин в даних системах.

Під IC розуміється безліч пов'язаних різними відносинами документів, що описують деякі сутності (об'єкти, факти або поняття).

В наші дні найчастіше застосовуються два підходи: інтеграція по типу «точка-точка» (point-to-point integration) i інтеграція по шині сервісів (services bus integration).
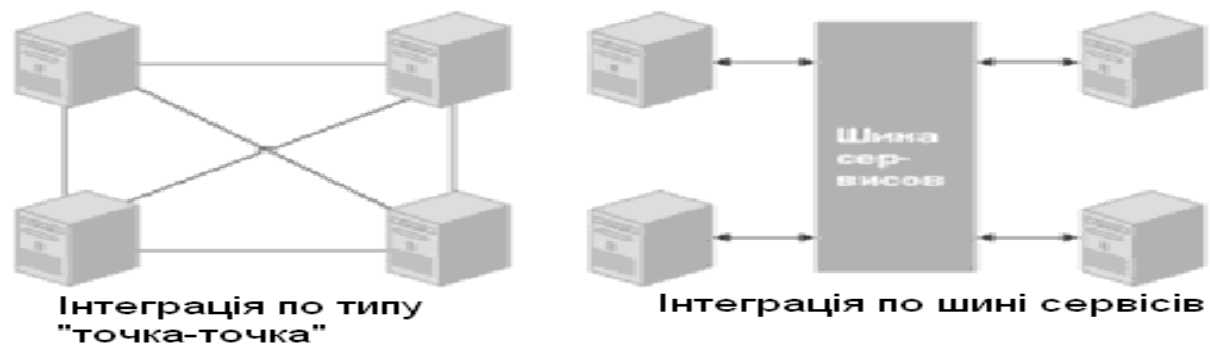

\section{Рис. 1. Ілюстрація моделей підходів до інтеграційних платформ}

Можна виділити 5 рівнів інтеграції:

I. Інтеграція бізнес-процесів - заснована на визначенні, реалізації та управлінні процесами обміну інформацією між різними бізнес-системами.

II. Інтеграція додатків - заснована на об'єднанні даних або функцій однієї програми 3 іншим, завдяки чому забезпечується інтеграція, близька до реального часу.

III. Інтеграція даних - заснована на ідентифікації та каталогізації даних 3 метою їх подальшого використання.

IV. Інтеграція на основі стандартів заснована на використанні стандартних форматів даних (наприклад, CORBA, JavaRMI, XML).

V. Інтеграція платформ - стосується процесів i інструментів, за допомогою яких системи можуть здійснювати безпечний i оптимальний обмін інформацією.
Інтеграція бізнес-процесів являє собою автоматизацію бізнес-процесів організації на основі єдиної інфраструктури по створенню i управлінню бізнес-процесами. Така інтеграція дозволяє об'єднати в єдиний бізнес процес дії, що виконуються в різних прикладних системах. Така інтеграція дозволяє:

- моделювати бізнес-процеси;

- забезпечити дотримання

правил виконання бізнес-процесів;

- надати користувачам єдиний інтерфейс для виконання завдань в рамках бізнес процесів;

- забезпечити контроль над виконанням i аудит бізнес-процесів;

- вносити зміни в бізнес-процеси відповідно до вимог бізнесу;

- отримати дані для аналізу виконання та оптимізації бізнес-процесів.

Інтеграція додатків за даними являє собою організацію взаємодії додатків за допомогою 
передачі даних, між цими додатками, без модифікації або 3 мінімальною модифікацією самих додатків. При цьому дані можуть передаватися як в початковому вигляді, так i 3 виконанням необхідних перетворень.

Гарантія якісної інтеграції додатків i бізнес-процесів - це інтеграція даних і систем баз даних.

На цьому рівні 3 метою інтеграції дані повинні бути:

1) ідентифіковані (тобто вказано їх місце розташування в розподіленій системі);

2) каталогізовані;

3) повинна бути побудована модель метаданих (тобто опис даних про дані).

Після завершення трьох цих етапів дані можна спільно поширювати або використовувати в системах баз даних.

Серед цих стандартів відомі специфікації:

1. COM / DCOM (Component Object Model / Distributed Component Object Model) фірми Microsoft;

2. Enterprise Java Beans - EJB (основний конкурент DCOM) 3 протоколом Java Remote Method Invocation (Java RMI) фірми Sun Microsystems;

3. Специфікації компонентів в архітектурі CORBA, підтримувані консорціумом OMG;

4. Стандарти компонентної розробки Webдодатків, запропоновані консорціумом World Wide Web Consortium (W3C) - XML (англ. EXtensible Markup Language - розширювана мова розмітки).

Як правило, засобами інтеграції додатків в даній групі засобів виступають служби програмного забезпечення проміжного шару (middleware). Такі служби іноді називають сполучним програмним забезпеченням. Вони забезпечують прозору роботу додатків в неоднорідному мережевому середовищі, надаючи їм послуги у вигляді інтерфейсів прикладного програмування (API), щоб забезпечити взаємодію частин додатків, розподілених по різним вузлам корпоративної мережі.

До служб middleware, перш за все, відносяться служби виклику віддалених процедур RPC (Remote Procedure Call), обміну повідомленнями та посередники (брокери) запитів до об'єктів ORB (Object Request Brokers), монітори транзакцій.

Завдяки використанню зазначених вище стандартів при компонентній розробці додатків, стає можливим широко реалізувати на практиці переваги повторного використання компонентів - підвищення продуктивності праці при розробці, простоту застосування, однаковість структури додатків.

Щоб завершити інтеграцію систем базової архітектури, апаратного та програмного забезпечення - необхідно інтегрувати рознесені частини гетерогенної мережі (тобто $є$ різні машинні архітектури та операційні системи).

Інтеграція платформ стосується процесів i інструментів, за допомогою яких ці системи можуть здійснювати безпечний i оптимальний обмін інформацією. В результаті, дані можуть безперешкодно передаватися по різним програмам.

У рамках напряму “клієнт-сервер” існують два основних “діалекти”: “тонкий” клієнт; “товстий” клієнт.

У системах на основі тонкого клієнта використовується потужний сервер баз даних високопродуктивний комп'ютер і бібліотека так званих збережених процедур, що дозволяють робити обчислення, що реалізують основну логіку обробки даних, безпосередньо на сервері.

Клієнтський додаток, відповідно, пред'являє невисокі вимоги до апаратного забезпечення робочої станції.

Товстий або Rich-клієнт в архітектурі клієнт-сервер - це комп'ютер, що забезпечує розширену функціональність незалежно від центрального сервера.

Як правило, сервер в цьому випадку є лише сховищем даних, а вся робота по обробці та поданням цих даних переноситься на машину клієнта.

Переваги - товстий клієнт володіє широким функціоналом на відміну від тонкого; режим роботи багатьох користувачів; надає можливість роботи навіть при обривах зв'язку з сервером; висока швидкодія.

Недоліки - великий розмір дистрибутива; багато в роботі клієнта залежить від того, для якої платформи він розроблявся; при роботі 3 ним виникають проблеми 3 віддаленим доступом до даних; досить складний процес установки та настройки; складність поновлення і пов'язана 3 нею неактуальність даних.

В даний час відомі наступні реалізації товстого клієнта: ArchiMed - медична інформаційна система; R-Keeper Delivery автоматизація доставки готової продукції; RKeeper POS-ITV - система відео контролю; RKeeper Self-Service - $\quad$ система самообслуговування; R Keeper - автоматизація ресторанного бізнесу; SET Prisma - система контролю касових оперцій; Shelter автоматизація готелів; StoreHouse - облікова система ресторанного бізнесу; Time-Keeper система обліку робочого часу; Абонемент автоматизація фітнес і спа-центрів; АТОЛ робоче місце касира; Касовий програмний модуль Кристал-УКМ; Касовий програмний модуль Супермаг-УКМ.

Приклади тонких клієнтів: Thinstation дистрибутив GNU / Linux, розроблений спеціально для створення тонких клієнтів; LTSP 
(англ. Linux Terminal Server Project) - пакет доповнень для GNU / Linux, що дозволяє підключити велику кількість низькопродуктивних тонких клієнтів до сервера; OpenThinClient; Windows CE; Бездискова станція; Термінальний доступ; Virtual Network Computing.

Висновки. На сьогоднішній інформаційні системи активно розвиваються, i обсяг оброблюваних даних зростає експоненціально, також змінюється i форма їх подання. Об'єднання даних від всіх використовуваних в оборонному відомстві інформаційних систем буде досить складно, а зміна таких систем може бути досить дорогою.

Існуючим технікам інтеграції даних для повноцінного вирішення це завдання не вистачає як масштабованості, так i функціонального охоплення. Ці підходи в основному концентруються на простому переміщенні даних 3 однієї системи в іншу i застосуванні трансформації i агрегації до елементів даних.

Вирішити цю проблему допоможе використання методів семантичної інтеграції. На сьогоднішній день це активно розвивається і перспективна область досліджень.

\section{СПИСОК ВИКОРИСТАНОЇ ЛІТЕРАТУРИ}

1. Балдин К. В. Информационные системы в экономике / К. В. Балдин, В. Б. Уткин. - М. : Дашков и Ко, 2015. - 395 с.

2. Вичугова А. А. Информационные технологии : учеб. пособие / А. А. Вычугова, В. Н. Вичугов, Е. А. Дмитриева, Г. П. Цапко. - Томск : Том. политехн. Ун-т, 2011. - 84 с.
3. Гарсиа-Молина Г. Системы баз данных. Полный курс / Г. Гарсиа-Молина, Дж. Ульман, Дж. Уидом. — М. : Вильямс, 2003. - 1088 с.

4. Голицына О. П. Информационные системы : учеб. пособие для вузов / О. П. Голицына, Н. В.

Максимов, И. И. Попов. - М. : ФОРУМ, 2009. $495 \mathrm{c}$.

5. Зауфер Г. Шаблоны для информационного сервиса / Зауфер Гюнтер, Мэй Сельваж, Эойн Лейн, Билл Мэтьюс. - URL :

http://www.ibm.com/developerworks/ru/library/wssoa-infoserv1/, 2007.

6. Дубина О. Обзор паттернов проектирования / О. Дубина. - URL :

http://zeus.sai.msu.ru:7000/SE/project/pattern/p_4.sht ml\#5.2.1, 2005.

7. Информационные системы в экономике : учеб. для вузов / под ред. проф. Г. А. Титоренко. - М. : Юнити-Дана, 2012. - 464 с.

8. Черняк Л. EDA как очередная инкарнация SOA / Л. Черняк // Открытые системы. - 2006. - № 9.

9. Черняк Л. Интеграция данных: синтаксис и семантика / Л. Черняк // Открытые системы. 2009. — № 10.6

10. Лондон Дж. Управление информационными системами. - 7-е изд. / Дж. Лондон, К. Лондон; пер. с англ. под ред. Д. Р. Трутнева. - СПб. : Питер, 2005. - 912 с. - Сер. «Классика МВА»

11. Свитинбенк П. Создание бизнес-процесса с помощью инструментов Rational и WebSphere / П. Свитинбенк, Х. Бадави, Дж. Хи. - IBM Redbooks, 2007.

12. Luckham D. The Power of Events: An Introduction to Complex Event Processing in Distributed Enterprise Systems / David Luckham // AddisonWesley Professional. 2002. - 1 ed.

13. Rahm E. A Survey of Approaches to Automatic Schema Matching / Erhard Rahm, Philip A. Bernstein // VLDB JOURNAL. - 2001.

Стаття надійшла до редакції 06.07.2017

Кирпичников Ю. А., к.Т.н.;

Адрощук О. В.;

Петрушен Н. В

Центр военно-стратегических исследований Национального университета обороны Украины имени Ивана Черняховского, Киев

Анализ понятия интеграционной платформы, ее виды, характеристики и методы интеграции информационных систем.

Резюме. Статья раскрывает понятие интеграционной системы и ее роль для Вооруженных Сил Украины. Проанализированы виды интеграционных систем, характеристики и методы интеграции информационных систем.

Ключевые слова: информационные системы, интеграция, методы интеграции.

Y. Kirpichnikov, PhD;

O. Androshchuk;

N. Petrushen

Center for Military and Strategic Studies of the National Defence University of Ukraine named after Ivan Chernyhovsky, Kyiv

Analysis of the concept of integration platform, its types, properties and methods for integrating information systems.

Resume. The article reveals the concept of integration system and its role for the Armed Forces of Ukraine. Analyzed the types of integration, performance and methods of integrating information systems.

Keywords: information systems integration, integration techniques. 